\title{
SANITARY FORUM: THE ROYAL SOCIETY OF TASMANIA AND PUBLIC HEALTH REFORM 1853-1911
}

\author{
by Stefan Petrow
}

\begin{abstract}
Petrow, S. 2013 (17:xii): Sanitary forum: The Royal Society of Tasmania and public health reform 1853-1911. Papers and Proceedings of the Royal Society of Tasmania 147: 1-10. https://doi.org/10.26749/rstpp.147.1 Department of History and Classics, School of Humanities, University of Tasmania, Private Bag 41, Hobart Tasmania 7001, Australia. Email: Stefan.Petrow@utas.edu.au
\end{abstract}

In the nineteenth century Tasmania experienced a number of epidemic diseases like scarlet fever, diphtheria and, most deadly of all, typhoid. Sanitary reformers attributed the epidemics to contaminated water supplies, accumulations of decomposed rubbish, poorly built houses and the absence of underground drainage schemes. Leading reformers, most notably Dr Edward Swarbreck Hall, were Fellows of The Royal Society of Tasmania and used the society as a forum to identify the causes of epidemic disease and to explain the public health reforms that would prevent death and illness. Lectures and papers by medical doctors, sanitary engineers, and statisticians drew on the latest thinking in sanitary science and helped build momentum for public support of such reforms. This paper examines the arguments of sanitary reformers and the reaction to their interventions and concludes that between 1853 and 1911 the Royal Society was the main forum for debate on public health reform in Tasmania.

Key Words: epidemic diseases, sanitary science, statistics, public health, doctors, The Royal Society of Tasmania

\section{INTRODUCTION}

One of the most striking developments in England and Wales between 1700 and 1911-15 was the decline in the crude death rate from 27.9 deaths per 1000 living, to 14.3 deaths and the increase in average life expectancy at birth from 37.1 years in 1701 to 53.5 in 1910-12 (Harris 2004). In the last two decades of the nineteenth century, "the rate of overall mortality decline noticeably accelerated, and the early decades of the twentieth century witnessed a precipitous reduction in mortality" (Bell \& Millward 1998, p. 223). Around 1840 infectious diseases were responsible for about $40 \%$ of all urban deaths, but by 1900 this had dropped to less than 20\% (Szreter \& Hardy 2000). Historians have offered various explanations for the conquest of disease and the decline in mortality, especially in the nineteenth century. These included the development of "new scientific medical procedures and discoveries", changes in the virulence of diseases, improved medical attendance and education, improved nutrition and public health reform (Berridge 1990 , p. 195). While it remains true that it will "never be possible to apportion credit with total accuracy to the many preventative measures that contributed to the decline in urban mortality", historians have tried hard to win converts to their preferred explanation and contributed to a lively debate (Kunitz 1993 p. 291). Medical historian Milton Lewis has surveyed a similar debate in Australia and concludes that by 1900 disease was prevented "through environmental sanitary regulation - reinforced by publicly run reticulated water and underground sewerage systems, at least in the larger colonial cities - and controls over infectious diseases through the practice of notification, inspection, disinfection and isolation" (Lewis 2003, p. 72).

The debate amongst historians on the causes of disease, the methods to stop their spread and the reasons for mortality decline also occurred in nineteenth century Britain. The forums for such debates included august scientific bodies like the Royal Society in London (Hall 1984, Batty Shaw 1968) and in Edinburgh (Campbell \& Smellie) as well as the Royal Medical and Chirurgical Society (from 1907 the Royal Society of Medicine) (Davidson 1955, Hunting
2002). But debates were also carried on in a number of other, more specialised bodies such as statistical societies (Cullen 1975), epidemiological societies (Lilienfeld 1978) and the Social Science Association (Huch 1985, Goldman 2002). Debate was stimulated not only by meetings of these societies, but also in their respective publications and in more general magazines, quarterlies and reviews (generally see Daunton 2005).

The aim of this paper is to examine the role played by The Royal Society of Tasmania, Tasmania's pre-eminent scientific and cultural institution, in acting as a forum for the discussion of public health reform and medical issues in the nineteenth and early twentieth centuries. Doctors and sanitary reformers used meetings of the Royal Society to argue the case for sanitary reform, but their views did not always go uncontested and some opposition to reliance on expensive public health measures did surface at meetings. Papers presented at Royal Society meetings often referred to British developments and varied from statistical analyses describing the state of health, propositions on the causes of infectious diseases, especially typhoid, and methods to combat disease and improve public health, in particular by improving water supply and building an underground sewerage scheme for Hobart.

Established in 1843, The Royal Society of Tasmania is Australia's oldest scientific society. It was formed "to develop the physical character of the Island and illustrate its natural history and productions" (Pearson 1943, pp. 224-26, Somerville 1943). Its aim was broadened in 1907 to include "the prosecution of the study of science in its various branches" and in 1914 the aim was enlarged to become "the advancement of knowledge" for the benefit of Tasmania. Various sections were formed on different subjects. These sections included Botany, Zoology, Geology, Palaeontology, Anthropology and History and Geography (Petrow 2003). Two sections are of direct relevance to this article and reflected the sizable number of medical doctors who had always been associated with The Royal Society of Tasmania (Hoare 1969, Paull 2011). One was the Physical, Mathematical and Mechanical Section, which entailed an interest in health and lasted only briefly in the 1860 s 
(Winter 1972). The other section was the Medical Section, which existed from 1896 to 1911 (Somerville 1943). In 1907 a reorganisation of the Royal Society resulted in the formation of Section B on Medical Science, but official publications still referred to the medical section (PPRST 1907). The Launceston district of the Victorian branch of the British Medical Association was formed in 1897 (Launceston Examiner 1897), but it made no effort to affiliate with the Royal Society and periodically held its own lectures on technical subjects (Launceston Examiner 1898).

The most significant contribution to public health reform was the number of articles on health matters published in the Papers and Proceedings of the Royal Society of Tasmania. The articles were usually published in local newspapers and generated debate inside and outside the society. Royal societies in other colonies held lectures and published articles on health as an important "public" issue (Inkster \& Todd 1988), but it does not appear that medical sections were formed in Queensland (Marks 1959), South Australia (Rogers 1922) or Western Australia (Jenkins 1965), while in Victoria the medical section, like other sections, functioned "either not at all or, at the best, only spasmodically" after 1858 (Pescott 1961, pp. 13, 23). In New South Wales a Medical Science section was formed in 1876 and was one of the "most active" until separate societies and a medical school at the University of Sydney were established (Elkin 1968 , p. 22).

Many of the articles published by The Royal Society of Tasmania before 1880 were not "theoretical and speculative" or even of particular "scientific" interest (Winter 1972, pp. 35, 54, 71). Instead, the articles were "practical, useful contributions, which would assist settlers in a new land". Lectures also dealt with "matters of public interest" and helped stimulate public debate (Somerville 1943, p. 207). As Pearson (1943, p. 226) put it, Society Fellows courageously promoted "new ideas and ideals, a process which is generally anathema in an isolated, self-contained community". The articles on health and medical issues reflect that assessment and were intended to alert the Tasmanian community to the latest developments in sanitary science that could help reduce the incidence of infectious and other diseases. We can analyse the kind of articles published in two phases. The first phase, between 1853 and 1896, dealt predominantly with sanitary reforms of interest to the Tasmanian community and in the second phase, between 1896 and 1911, doctors showed more interest in technical medical matters and were more inward-looking, but some papers on sanitary reform were discussed.

\section{PHASE 1: 1853-1896}

Public health attracted most interest amongst Fellows of The Royal Society of Tasmania after epidemics of infectious diseases occurred. In November 1853 a paper by the President, Lieutenant-Governor William Denison, drew a direct connection between the recent outbreak of scarlet fever and the "the present imperfectly drained state of Launceston and Hobart Town" (Courier 1853 p. 2). Denison had been a member of the Health of Towns Commission in 1844, which enquired into the condition of large towns in England and Wales, and he quoted from the Commission's reports to highlight the importance of drainage and sewerage to "the physical and moral well-being of the community" (Denison 1854 , p. 371). The meeting resolved to draw the attention of the municipal councils of Hobart and Launceston to Denison's paper, which was published in 1854 (Denison 1854). The Launceston municipal council took Denison's admonition to heart and in March 1857 aldermen asked him to choose the best scheme for sewering the town (Petrow 2003b). He chose one called "Sub Spe" by W.C. Bennett, Assistant Engineer in charge of Sewerage, Sydney and W.R. Wade, Assistant Engineer of the Sydney Water Works. The Launceston Council began work on "Sub Spe" in August 1860.

Another contributor on health matters was one of Hobart's leading doctors, Dr E.S.P. Bedford, who attributed the scarlatina outbreaks of 1852-3 to the disease's "peculiar germ, or poison", but its "spread and its severity [was] influenced by all those circumstances which impair general health" (Bedford 1854, p. 460). Bedford also contributed one of the few technical papers, on the origins of nervous shock (Bedford 1863).

The most prolific contributor on public health matters before 1896 was Dr Edward Swarbreck Hall. For being the first doctor "to preach the gospel of public health with an inspired intelligence and courageously to fight for health reforms in the face of great obstruction", Howard Cumpston (The Mercury 1923), the first Director-General of the Commonwealth Department of Health, anointed Hall as "The First Australian Sanitarian”. Born in 1804, Hall studied medicine at Liverpool, England and completed further studies at the School of the Royal College of Surgeons in Dublin and at St Bartholomew's Hospital Medical College in London (Haynes 1978).

He practised medicine in Liverpool but, after his wife's health declined, decided to move to the healthier climes of Van Diemen's Land, arriving in 1833. His various appointments in different parts of the penal colony helped broaden his medical experience, in particular in dealing with epidemics of infectious diseases. Such diseases devastated local communities and Hall developed an interest in how to prevent their recurrence. Hall resigned from government service in 1855 and resumed private practice at Hobart, thus freeing him "from the many restrictions, both political and social, which Government service imposed" (Haynes 1978, p. 138). Soon Hall was transformed from "the conscientious Government servant who was anxious to abide by the regulations to the outspoken medical and social reformer".

In his new role as sanitary conscience, Hall had ample scope for improving the situation in Hobart. The city was unsewered, the water supply was inadequate, public and private buildings lacked ventilation and overcrowding was common (Petrow 1995). The municipal council and most citizens were apathetic and did nothing to remove the rubbish that littered streets and backyards, all exposing residents to infectious disease. In his battle against apathy, conservatism and vested interests, Hall found allies in the local press, first in the Tasmanian Daily News and later The Mercury (Haynes 1978). They published his speeches and papers to The Royal Society of Tasmania and his letters and statistical studies, as well as reporting on developments in public health in Britain and America. The press also fully exposed the impact that epidemic disease had on urban residents.

While Hall was a passionate critic, he did not let emotion outweigh reason. He based his arguments on first-hand, detailed, empirical research, in the tradition of the great English sanitary reformer Edwin Chadwick (Finer 1952). As Hall noted, "the master minds of the profession are now 
assuming the first duty of medical skill to be to prevent disease" and that the collection of facts and figures were "the great levers which enabled sanitary reformers to effect their brave and bloodless victories" in saving human lives (Hall 1862 , p. 42). Hall relied on vital statistics to demonstrate the impact of epidemics. In the mid-1850s he spent endless hours in the Registrar-General's office investigating returns and compiling tables of statistics and he later became a member of the Statistical Society of London (Haynes 1978).

In his papers to the Royal Society, Hall $(1863 \mathrm{a}, \mathrm{b})$ was a strong advocate of sewering Hobart. He marvelled at how "the application of the science of Hydraulics" had "largely" resulted in "the great triumphs of improved health, increased comfort and prolonged life" in the cities and towns of Great Britain (Hall 1863a, p. 5). More significant was Hall's fruitful collaboration with another Royal Society of Tasmania Fellow, the Registrar-General Francis Abbott, in investigating the connection between the occurrence of disease and the weather (Haynes 1978). They attempted to prove that it was upon the hourly and daily changes of atmospheric phenomena that the healthiness or otherwise of any climate depended. They postulated that the amount of ozone in the atmosphere might account for the lower mortality rate in country districts than in Hobart and that generally Tasmania's large amount of ozone helped mitigate the effect of some epidemic diseases, such as influenza. Hall was "not aware that I have been anticipated in ... attempting to minutely apply the treasures of vital statistics, of daily meteorological observation, of accumulated medical experience, to elaborate laws of health, and produce a harmonious union of our respective labours" (Curson 1985, p. 109).

Hall published "very numerous and instructive" papers on climate and health between 1856 and 1872 in the Papers and Proceedings of the Royal Society of Tasmania (Morton 1900-1901, p. 124). Hall's reports on the health of Hobart compared the number of deaths in the month with that of the previous month, and then with the same month in the preceding six years (Haynes 1978). He divided deaths into age groupings and into fifteen different classes or causes of death, ranging from zymotic diseases to old age. The meteorological information included readings of the barometer, thermometer, and the wet bulb thermometer, records of solar intensity, elastic force of vapour, rain, wind force, and amount of ozone. Hall ended by summarising the positive or negative impact of the weather, and providing advice on future action.

Hall's statistical analyses showed that Hobart experienced a very high degree of infant mortality and that the meteorological phenomena were characterised by large fluctuations in barometric pressure and temperature (Haynes 1978). Hall linked the two factors and added a third, the carelessness of man. He found that a rising barometer with a falling thermometer was invariably followed by an increase in deaths both of adults and children. Croup, convulsions, diarrhoea and dysentery were the main causes of infant mortality. Hall became especially agitated by the high mortality rate at the Queen's Orphan School and made enemies of influential senior members of the medical profession by bringing this fact to public notice at the September 1857 meeting of the Royal Society. Dr E.S.P. Bedford, the Orphan School's Medical Officer, described Hall's statistics as "erroneous and unjust" and "founded upon insufficient data" (Courier 1857a, p. 2). Bedford claimed that Hall had selected two or three years when deaths were very high as his mean "instead of an average being deduced from a series of a dozen years or more". Bedford attempted to divert attention from himself by questioning Hall's assertion that Tasmanian wheat was deficient in gluten, a subject on which experts differed (Hobart Town Daily Mercury 1858a, b, c). Hall had suggested that lack of nutrition contributed to the death rate and therefore that children in the Orphan School should receive a larger ration of animal meat to ensure that they consumed an adequate amount of nutritious food. Fellows were concerned that, if Hall's paper was published, the reputation of the wheat industry would be damaged and this would be detrimental to Tasmania's economy. After a lengthy debate, they overwhelmingly decided not to publish Hall's paper because it was based on questionable evidence (Courier $1857 b, c)$. Hall was not deflated by this decision and dismissed Bedford's "old-fashioned and unscientific approach to medicine" (Rimmer 1981, p. 81). Whether due to Hall's agitation or not, during the first half of the 1860s deaths at the Orphan School declined in line with the general death rate (Hall 1865).

In 1860 Hall's contribution to the study of disease was recognised when he became a corresponding member of the Epidemiological Society of London, which was becoming an influential medical and scientific body (Haynes 1978). He was also made an Honorary Member of the Medical Society of Victoria, which proclaimed him to be "the ablest authority on Medico-Vital Statistics in the Southern Hemisphere" (Haynes 1978, p. 280). By the 1860s Hall had established a world-wide reputation as a medical statistician and a sanitarian. He was supremely confident of the correctness of his mission, was convinced that the evils of Hobart were due to local and remedial causes and was heartened by the improvements that were slowly gaining ground. He continued to criticise the status quo and to suggest practical reforms based on his wide reading in medical journals and his correspondence with sanitarians around the world.

In the 1860s Hall had been, in effect, the unofficial Health Officer for Hobart. In his articles in the Papers and Proceedings of the Royal Society of Tasmania and in small articles on particular subjects for the press, his work as a sanitarian was limited to pointing out abuses. In a long paper read to the Royal Society in March 1872 entitled "Climate and Statistics in Tasmania" based on the statistical tables he had compiled between 1857 and 1871 (PPRST 1872 , pp. 3-4) and later published separately, Hall conceded that statistically deaths in Tasmania had undergone "a great reduction of late years", but he lambasted the Hobart municipal council for its neglect of sanitary matters. He warned that "man's care has so far done little to obviate those hygienic drawbacks which the concentration of a city population will produce whatever may be the climatic and local advantages, unless special care be taken" (Hall 1872, p. 21). The President of the Epidemiological Society, Inspector-General Robert Lawson, described Hall's study as "a model for any work of this kind" (The Mercury 1873 , supplement, p. 2).

The 1875 epidemics of measles and typhoid shook aldermen out of their complacency and with press and government encouragement they appointed Hall as Health Officer in November 1875 (Petrow 1995). Throughout his period as Health Officer, Hall received little support from aldermen and lacked legal power to carry out effective sanitary reform without that support. To be sure, some 
successes were achieved. In 1880, for example, the council was empowered to borrow money to improve the water supply and to clean up and permanently improve the Hobart Rivulet, which Hall had advocated. But generally Hall's message that expenditure on preventive measures, such as an underground sewerage scheme, would save money in the long term was not easily grasped by cheese-paring aldermen before his death in July 1881 .

Between 1875 and 1896 the Papers and Proceedings contained a number of papers that highlighted sanitary problems in Tasmania. In 1875 Government Statistician E.C. Nowell, noting Tasmania's economic disadvantages, suggested that her great advantage was her "superior" climate, which was especially beneficial for the health of children and tourists (Nowell 1875). Tourists were attracted by cool temperatures, beautiful scenery and "a reputation for salubrity", but they would be deterred from visiting the island, Nowell warned, unless Tasmania adopted "efficient means of removing all those causes of disease which are under our control" (Nowell 1875, p. 115). The Bishop of Tasmania, Charles Henry Bromby, a member of the Statistical Society of London and a former secretary to the statistical section of the British Association for the Advancement of Science, thought Nowell's paper was of "importance to the community at large" (The Mercury 1875, p. 3). He suggested that Hobart's chance of becoming "the naval station of the colonies" depended upon "the proofs we can give as to the salubrity of our climate".

Bromby presented his own thoughts on the relationship between water and disease in 1878 . He blamed outbreaks of typhoid, scarlet fever and diphtheria on drinking from "stagnant wells, befouled by vegetable decomposition, animal refuse, and disgusting drains and miasmatic cesspools" (Bromby 1878, p. 56). He subscribed to the germ theory of disease causation and urged "the Sanitary Reformer" to prevent germs from growing and multiplying by protecting Tasmania's "noble water-fields" from contamination. Bromby quoted Swarbreck Hall, who thought Bromby's address would have "a beneficial effect" because when "respected and intelligent gentlemen took up sanitary subjects, it would have more weight with Government and local authorities than anonymous letters to newspapers" (The Mercury 1878a). Bromby's paper was reprinted in The Mercury (1878b).

Bromby thought expense might be one obstacle to reform, but another was differences over disease causation. The Secretary and Royal Society stalwart Dr James Agnew, observed that, although the germ theory was "a good working theory, it was well to recollect its correctness had never yet been actually proved" (The Mercury 1878a, p. 3). He believed that infectious diseases occurred "de novothat is without the action of any pre-existing germ". He cited the anti-germ theory research of Dr Benjamin Ward Richardson, F.R.S. (1877) (Worboys 2000). Richardson, a pioneer of the British sanitary movement, suggested, claimed Agnew, that infectious diseases were caused by "a poison secreted by the individual", which was "conveyed from one individual to another by the air, by various fluids, or by personal contact" and produced "certain (catalytic) changes in the secretion of the part to which it was applied". In some cases poisonous secretions resulted from "certain nervous influences inducing diseased local secretions" and thus infectious diseases might begin "de novo".

Another skeptic of the germ theory was Nowell's successor, Government Statistician Robert Mackenzie Johnston, who was a "prolific contributor of papers", mainly on geological and statistical topics (Winter 1972, p. 74). Johnston was influenced by a paper published in the Journal of the Statistical Society of London by B.G. Jenkins (1879), who posited "a probable connection between the yearly death-rate of England and the planet Jupiter in his orbit" (Johnston $1884 a$, p. 236). In 1884 Johnston, after completing his own analyses, suggested that fluctuations in death rates in the Australian colonies were due to "some super-terrestrial influence of a variable character, which has the effect of intensifying or modifying the death-rate to such an extent that the local causes appear as mere ripples on the swell of a great wave in conjunction with it" (Johnston 1884a, pp. 237-38). In particular he identified the rise and fall in death rates as linked to Jupiter's movement between "aphelion" and "perihelion". In Australasia the death-rate was low "during years of sun-spot maxima" and high "during years of sun-spot minima". Australia's mean death rate over the twenty years to 1884 was lower than Europe's because it was "comparatively unaffected by those artificial evils attended upon crowded centres of population" and had a "fortunate immunity from the pestilence of war". Freedom from "artificial disturbances" made Australasia "a more sensitive index of complex super-terrestrial influences". But Johnston concluded that "the death-rate coincidences are not sufficiently broad and regular to justify prediction" and the phenomena were "more suggestive than conclusive".

Based on his reading of an abstract of Johnston's paper in The Mercury, distinguished local astronomer Alfred Biggs (1884, p 277) took issue with Johnston over whether deathrate fluctuations "might correspond with and be dependent upon either the sun-spot periodicity or the position of Jupiter in his orbit". Biggs argued against coupling "the two phenomena of Jupiter and sun-spots, inasmuch as the periods, although very nearly equal, are not quite so". As Jupiter's mass was "less than one-thousandth part of that of the sun and his mean distance 480 millions of miles", Biggs thought it "difficult to conceive of any particular influence that he could exert upon the sun under any circumstances". Biggs (1884, pp. 278-9) did, however, countenance the possibility that "physical changes in the sun, such as variation in spottedness", could affect "our mortality curve", but ultimately concluded that "solar observations and vital statistics have not run together long enough to establish the fact of any connection between them". He observed that the rise in death-rates in the last two years correlated with "a period of abnormal telluric disturbance" and with "abnormal atmospheric conditions, as shown by our recent sunset glows". If there was a connection, Biggs (1884, p. 280) rightly pointed out that, "unlike sanitary arrangements which are supposed to engage the attention of our municipal authorities", the extra-terrestrial phenomena were "absolutely beyond our control”. Johnston (1884b, pp. 280-81) welcomed Biggs' interest in the subject, but regretted that he read an abstract and not the full paper. This led him to assume "erroneously" that "the relations commented upon are simple instead of complex" and to assign "mutual inter-dependence" between phenomena where Johnston only "observed coincidence". Johnston acknowledged "many unexplained anomalies due to unknown and complex relations" and said that more proof was needed.

Esoteric debates like the one between Johnston and Biggs were uncommon. Tasmanians became increasingly preoccupied with tackling more fundamental, practical 
problems such as the pollution of water, which was the subject of a paper by the Government Analyst and chemist W.F. Ward (The Mercury 1931). In 1885 the Sanitary Officer of the Launceston municipal council J.G. Bushman sent Ward his analysis of water samples from different locations, which showed "painful neglect of the simplest necessary health precautions" (Ward 1885, p. 116). Ward (1885, p. 123) subscribed to the view that typhoid was "spread by the contamination of water or air by a specific poison derived from the discharges of infected persons" and that this poison consisted of "living germs, although they have not yet been absolutely identified". Ward (1885, p. 124) thought it of "the highest importance" that the water supply of towns "should be preserved from the risk of contamination by the prohibition as far as possible of all settlement on gathering grounds". Ward's paper was well received by Johnston, Drs A.B. Crowther and H.A. Perkins, and Richard Bastow, who had worked for the Health Department of the Manchester City Council (Petrow 1995). There seemed to be general agreement that germs contributed to the spread of disease and that sanitary reforms, including ensuring the purity of water, were needed to protect Tasmanians from further epidemics, but some issues remained unsolved (Ward 1885, pp. 125-30) Perkins asked: "Were the germs brought to the colonies by passengers in ships, or had they been present in the world from the beginning of all creation, ranking with the first origin of all things? Was it that the germs were not noxious - things to be hated-and not merely things for the transmission of disease to man, but having their own rank in the scale of creation? Was the fact of the transmission of disease by them a mere accident, or the result of man's own fault?” (Ward 1885, p. 128).

Perkins was disappointed that the Public Health Bill 1885 about to be presented to Parliament, left power to keep water supplies pure in "local hands, which, in his opinion, would not tend to work satisfactorily" (The Mercury 1885 , p. 4). Although municipal councils were notoriously lax in keeping water supplies free from contamination, they won the battle to retain that responsibility.

More positively, the enactment of the Public Health Bill created a Central Board of Health, which appointed Alfred Mault as its Engineering Inspector. Mault succeeded Hall as Tasmania's pre-eminent sanitarian. In a complementary paper to Ward's, Mault spoke on drainage and sewerage of Hobart to the meeting of The Royal Society of Tasmania in August 1886. The talk was an abridged version of his 1886 report on the sanitary condition of Hobart and was designed to stimulate debate on the relative merits of surface drainage and underground drainage (Mault 1886). Mault estimated that it would cost $£ 20,000$ to complete the system of surface drainage and that the annual cost of keeping it in working order, including $£ 9,000$ for emptying pails of nightsoil and paying interest on the $£ 20,000$, would be $£ 16,300$. Mault preferred an underground sewerage system, which would use water closets and carry sewage into the estuary's tideway. This system would cost $£ 60,000$ to build, with an annual cost of $£ 7,000$ including interest. This system entailed provision for "mechanical or chemical ... purification" of the sewage before reaching the outlets (Mault 1886, pp. 30-31). Hobart was especially suited to such a system because fifteen million tons of water flowed down the River Derwent each day and this large body of flowing water would easily accommodate $12 / 3$ tons of "solid faecal matter", but Mault was concerned about discharging "liquid excreta and house slops" (The Mercury 1886a, p. 3).
Mault's paper received a lukewarm response. Draughtsman and drawing teacher W.H. Charpentier noted how refuse, and even excreta from ships in the harbour and the Hobart Rivulet ended up on the nearby beach and he doubted that the sewage would be carried far enough away from Hobart (The Mercury 1886a). He preferred the dry earth system because it could produce "marketable manure" and typhoid was "always found wherever the water closet system was adopted". Others also supported the dry earth system and thought that Mault had underestimated the cost of an underground system. Dr Perkins supported Mault's proposal, but also wanted the outlets taken further out to sea. At a subsequent meeting, when Bastow read a paper questioning Mault's views, most Fellows tended to oppose Mault's scheme largely due to doubts about his estimated cost, concerns about the safety of water closets (sewer gas being a particular danger) and opposition to the pollution of rivers (The Mercury 1886b). Although Perkins and Mault effectively answered the critics, the opposition of the Royal Society Fellows largely reflected concerns of ratepayers, who would bear the heavy cost of underground drainage (Petrow 1995).

Johnston proceeded to investigate further the causes of death in Tasmania and presented his findings to the Royal Society in 1887 . He argued that the total death-rate as "a test of comparative health and sanitary condition" was "misleading" and cited Hobart as an example (Johnston 1887, pp. 22-23). When compared with Sydney, Brisbane, London and Adelaide, Hobart had the highest death-rate of 24.70 per 1000 in 1885 . But Hobart also had by far the highest number of deaths in people aged over 60 at 43.46 per cent of all deaths, the next closest being Adelaide at 18.80 per cent. The mean age of death in Hobart was also the highest at 74.30, with London next at 73.37, and Johnston argued that longevity was an important indication of the health of Hobart. When only deaths under 60 were considered, Hobart's death rate was the lowest at 13.97 per 1000, with Adelaide next at 15.42. Johnston also took into account other factors such as migration, the birthrate, the influence of climate and the season, the density of population and hygiene. Inevitably, Johnston remained partial to "cosmical or obscure causes", but he admitted that in England during the previous 20 years sanitation and improved medical treatment had done much to lower the death-rate of "younger lives" and believed that "human effort" could do much "to mitigate the intensities of attacks on disease, from whatever source they come, even if it cannot wholly subdue them" (Johnston 1887, p. 30).

Johnston's analysis was not without critics. Dr C.J. Parkinson questioned Johnston's age limits, especially fixing the upper limit at 60 instead of 65 or 68 (The Mercury 1887, supplement). More pertinently, Parkinson doubted that Johnston had made a case for the superior "health and sanitary condition" of Hobart and suggested comparing Hobart with "health resorts" with similar populations, such as Cheltenham, Hastings and Eastbourne rather than a large metropolis like London. It also made more sense to compare Hobart with colonial towns with similar climates like Christchurch and Dunedin, rather than with colonial capitals like Brisbane and Sydney. Parkinson thought it unnecessary to invoke "a hidden cosmical influence" as the cause of typhoid when local hygiene and seasonal influences more than adequately explained "this fearful epidemic of a filth disease amongst us". Mault feared that Johnston's paper would retard rather than aid sanitary work. Mault 
asserted that "sanitary science and the inculcation of the duty of cleanliness can override such cosmical influences as were at work". He thought that they should look at death from preventible disease as "a homicide chargeable to something or somebody".

Although by 1887 very few people doubted the efficacy of sanitary reform when it involved cleaning up the environment, Mault still found it hard going convincing Hobartians to accept the discharge of sewage into the River Derwent, but received encouraging support from the Royal Society when he delivered a paper on the topic in 1893 (Mault 1893). Support for sanitary reform was most certainly due to a series of typhoid epidemics that affected Hobart in 1887, 1888, 1889 and 1891 when the death of people in "the prime of life, especially males between the ages of 20 and 35 years, was unusually large" (Johnston 1896, p. 1). This resulted in the formation of pressure groups such as the Sanitary and General Improvement Association and the Women's Sanitary Association to push for sanitary reform (Petrow 1995). But Johnston told the Royal Society in 1896 of a noticeable drop in deaths from preventable diseases like typhoid in 1894 and 1895. Johnston (1896, p. 13) asserted that this drop had little to do with "local, artificial, or sanitary provisions" and its low death-rate made Hobart "pre-eminently one of the most healthy cities in the world". Johnston criticised sanitary "enthusiasts" for being "alarmists" who were "ever prone to exaggeration" and condemning the sanitation and health of Hobart as being "unexceptionally bad", which scared away tourists and their much needed money.

Statistics indicating "the comparative superiority" of Hobart did not go uncontested. Discussion after Johnston's paper produced different statistics and interpretations to show Hobart's high death rate from preventable diseases. Mault admitted that Johnston's statistics on general death rates proved Hobart to be "one of the healthiest cities in the world", but he was astonished by Johnston's implication that "better sanitary administration" had not reduced deaths in other Australian cities (Johnston 1896, pp. 16-18). Mault's statistics showed that typhoid was one disease that sanitary work could reduce and even eliminate and that Hobart, "though a very healthy place, may be made yet more healthy by the prevention of typhoid". Johnston remained adamant that sanitary changes alone could not explain the drop in deaths from typhoid and suggested that the role of "the increased knowledge of medical men in the treatment of such diseases, and the improved habits of the people" needed more acknowledgement. But he hoped his paper would not distract attention from "the importance of sanitation" (Johnston 1896, p. 21).

While typhoid absorbed most discussion at Royal Society meetings, it was not the only disease to cause concern. In 1896 Dr Gregory Sprott, newly-appointed Health Officer to the Hobart municipal council and fresh from an Intercolonial Medical Congress in Dunedin, spoke to Fellows about tuberculosis, "one of the most widespread diseases we have to deal with", which caused "more suffering to humanity than any other known disease at the present time" (Sprott 1896, p. 45, Roe 1999). Tuberculosis was another disease to cut off young men and women in their "prime" and those who did not die often became "chronic invalids, incapacitated for work". Although German doctor Robert Koch had identified "the bacillus tuberculosis", Tasmania had done very little to stop its deadly spread by for example minimising spitting by consumptives. The work of doctors would be bolstered if people were educated as to "the cause and nature of this disease and the measures which will prevent it" (Sprott 1896, p. 60). Meat and milk supplies needed to be tightly regulated and inspected and housing needed better ventilation.

\section{PHASE 2: 1896-1911}

In the late nineteenth century the colonies experienced an influx of doctors from Britain and, as many had been members of the British Medical Association (B.M.A.), they naturally sought to form colonial branches (Johnson \& Caygill). It appears that a Tasmanian branch of the B.M.A. was formed in 1889, but it had dissolved by 1892 (Johnson \& Caygill). Moreover, in the absence of a Medical School (onewas mooted in 1896) at the newly-formed University of Tasmania, doctors clearly felt a need to discuss aspects of their professional practice and new developments in medicine (Davis 1990). An obvious solution was to establish a more formal relationship with the pre-eminent scientific body, The Royal Society of Tasmania. In November 1896 a medical section of the Royal Society was formed with seventeen members, including six doctors who joined on 16 November (The Mercury 1896). The Royal Society generously granted the section $£ 12$ a year towards the cost of medical books, provided the section had not less than twelve members (Somerville 1943 RSA/A/5). Dr R.S. Bright was the first President. Trained in London, Bright began practising in Hobart in 1859 and became one of the leading doctors (The Mercury 1901).

At the annual general meeting of the Royal Society in 1897 Bright announced that nearly all the doctors in Hobart had "expressed their willingness to join" and preferred "to affiliate themselves as a branch of the Royal Society than to form an independent Medical Society of their own" (The Mercury 1897a, p. 3). At its first annual dinner in October 1898 Dr Butler thought the section had done "a large amount of good work" (The Mercury 1898c, p. 2). It gave doctors a chance to meet together and exchange ideas on "all matters relating to their professional work". It promoted "those kindly feelings which ought to exist amongst members of the profession". Section meetings were held in committee and were not reported in the press as were the monthly meetings of the Royal Society (The Mercury 1905a)

At meetings of the section members delivered papers on a range of "highly technical" medical topics (Somerville 1943 , p. 209). For example, of the seven papers given in 1897 Dr S.C. Jamieson spoke about a "New Method of Treating Empyema" (The Mercury 1898a, p. 3) and of the eight papers given in 1898, Dr Wolfhagen related "Some Unusual Complications after Laparotomy" (The Mercury 1899 , p. 4). Members exhibited specimens of various kinds such as in its first year a "large calculus", Tasmanian skulls and a horseshoe kidney (The Mercury 1898a, p. 3). The nature of the papers given at section meetings were not always specified after 1898 , but sometimes members read papers at the monthly meeting. In August 1898 Dr A.H. Clarke spoke about his "Notes on a Surgeon of the Tudor Period and his work" (The Mercury 1898b, p. 4). Clarke highlighted how "improvements in surgery since anaesthetics have combined to make operations so much easier and safer" (Examiner 1900a, p. 7). Some papers read at monthly meetings were also technical in nature. For example Dr Gerard Smith expounded on "The Biological 
Ancestry of Some Human Diseases" (The Mercury 1906a), Dr E.J. Roberts (1906-7) discussed anti-toxins in his "The Germ as a Friend in Therapuetics: Notes on the Opsonic Index" and Dr E.J.W. Ireland (1910) considered "Skin Diseases Treated by Blood Vaccine".

Public health remained a popular topic and Sprott gave two papers to monthly meetings. In July 1897 he trumpeted the virtues of cremation. Sprott argued that "as we become better acquainted with the life history of disease germs, and the part they play in the causation of infectious diseases, we will be forced, whether we like it or not, to find a more sanitary way of disposing of our dead than by our present mode of burial" (Sprott 1897, p. 13). Sprott thought that the religious and sentimental objections to cremation would be overcome in time by an educational campaign on its advantages (The Mercury 1897b). In 1898 he was even more impassioned in favour of an underground drainage system for Hobart and his paper, which was not published in full in the Papers and Proceedings, showed how an underground drainage scheme had reduced the death-rate from typhoid in "numerous cities and towns" (The Mercury 1898b, p. 4). He hoped that "no private or selfish interests" would stop a reform that would "improve the health of the people". Those present overwhelmingly supported underground drainage. Further papers by mainland sanitary experts, Jamieson (1902) and Wilkinson (1902), merely confirmed the effectiveness of a properly constructed underground drainage scheme and accompanying purification process. In 1903 an overwhelming number of ratepayers voted for such a scheme (Petrow 1995).

Another distinguished contributor on health matters was Dr J.S.C. Elkington, who served as Tasmania's Chief Health Officer from 1903 to 1909 . Elkington introduced two new subjects. In 1904 he analysed the link between insects and disease, noting the role of mosquitos in spreading malaria and fleas in spreading the plague. More pertinent to Tasmanians was the "ubiquitous" house fly, which conveyed on its feet and body "the germs of disease" (Elkington 1904, p. 11). Elkington thought that flies were responsible for "a fair proportion of cases of communicable disease", especially typhoid and even perhaps smallpox and urged housewives to eradicate them. Elkington was a pioneer in school hygiene (Roe 1984) and stressed the importance of that subject in a paper delivered to a receptive meeting in 1906. They could stop children "spoiling their eyesight, curving their spines, and doing themselves all sorts of injuries" if schools were "properly built and modern appliances [were] used" (The Mercury 1906b, p. 6). Elkington also believed in greater physical activity for school children and medical inspection of schools.

Elkington's most controversial paper was given in 1905 when he exhaustively discussed "Some Social and Economic Aspects of Health Work". Elkington asserted that the "standard of a community's progress" could be measured by "its sanitary administration and by the proportional fund allotted for the purpose" and said that how much was allocated by the State depended upon the level of public support (The Mercury 1905b p. 7). He estimated that Tasmania spent 2.16 pence per head of population on sanitary administration, but if six pence was spent they could achieve "real efficiency" and nine pence would be "absolute luxury", preventing outbreaks like Launceston's smallpox epidemic in 1903. Elkington pointed out that Tasmania was behind Victoria at 4.2 pence per head per year, New South Wales at 5.8 pence and New Zealand at 9.6 pence. While the major cities now recognised "the benefits of applied sanitation", most of Tasmania was "barbaric in its primeval insanitation". Elkington saw the solution in greater centralisation of sanitary administration as was the case in New Zealand (The Mercury 1905c, p. 7).

Giving papers was a normal part of Royal Society activities, but the medical section went further and acted as a lobby for doctors and health reform (The Mercury 1908a), often joining forces with the Launceston district of the Victorian branch of the B.M.A. in "matters of mutual interest" (The Mercury 1899, p. 4). Tasmanian doctors were far more organised before a Tasmanian branch of the B.M.A. was formed than McWhirter (2003) implies. In 1900 the medical section supported giving Launceston doctors more involvement in the running of the Launceston General Hospital (Examiner 1900b, Craig 1963). Both medical bodies combined to hold the Australasian Medical Congress in 1902 (The Mercury 1902a). In Hobart the medical section supported the establishment of a Maternity Hospital as long as patients could engage their own doctors (The Mercury 1902b), but opposed making tuberculosis a notifiable disease "without effective follow-up" (Roe 1999, p. 40). Following the smallpox outbreak in Launceston in 1903 , the medical section advocated "a more thorough system of vaccination" and giving power to the Central Board of Health to vaccinate compulsorily anyone who came into contact with a smallpox case. The section also supported building an infectious diseases hospital in Hobart and smaller hospitals in country areas (The Mercury 1908a) and establishing "a depot for the supply of humanised and pure milk" as "necessary for the conservation of infant life" (The Mercury 1909, p. 2).

None of these interventions seems to have been questioned, but in 1903, when the medical section opposed the confirmation of Dr Gerard Smith as Health Officer for Hobart because "such an important position" should not be held by "a homeopathic practitioner", the section did incur criticism (The Mercury 1903, p. 6). Writing to The Mercury, "No Close Borough" pointed out that the Royal Society had been formed to advance science and the study of natural history, but the medical section was travelling "a long way outside those functions" in attacking their "legally-qualified brother medical practitioner" (The Mercury 1903 , p. 6). If the doctors formed their own independent society, then they could black-ball anyone they wished, but they should not do so under the imprimatur of the Royal Society.

It appears that Hobart doctors were intent on defending their professional position and formed a Tasmanian branch of the B.M.A. in July 1911 when Sprott was elected its first Chairman (NS168/1/1, Rimmer 1981). Even then, the eighteen members of the section requested that the branch be allowed to affiliate with the Royal Society, which was agreed to "subject to certain conditions" (PPRST 1911, p. 401). But soon the affiliation lapsed and the B.M.A. merely paid an annual subscription for the use of the Society's room and the medical books (Somerville 1943). By 1914 two-thirds of doctors in Tasmania had joined the B.M.A., which became a powerful interest group (Rimmer 1981). Until 1916 the B.M.A furthered its aim to "promote the advancement of medical science" by encouraging members to give lectures on medical topics, but "clinical meetings had ceased entirely by late 1916 " and the protection of professional interests dominated (NS 168/1/1, McWhirter 2003, pp. 21-2, 79). After the departure of the medical 
doctors, papers on medical topics were rarely published in the Papers and Proceedings, which were dominated by papers on botany, zoology and geology.

\section{CONCLUSION}

In the nineteenth century infectious diseases proved to be deadly killers around the world and doctors and sanitarians spent much time debating the best methods to stop the spread of diseases like typhoid and tuberculosis. In Tasmania these issues were discussed in the newspapers whenever epidemics broke out, but The Royal Society of Tasmania, as the most highly respected scientific body, was a valuable forum for leading sanitary reformers such Drs Edward Swarbreck Hall, Gregory Sprott and J.S.C. Elkington, sanitary engineer Alfred Mault, statisticians E.C. Nowell and Bishop Bromby and the chemist W.F. Ward. The publication of the Papers and Proceedings of the Royal Society of Tasmania enabled sanitarians to present their arguments in some detail and these papers were often reprinted in the press. Drawing on developments in sanitary science in Britain, they argued that improving water supplies, drainage and sewage schemes, refuse removal and housing standards was the most effective way of lowering death rates and illness from diseases like typhoid and of making people healthier. Discussion in the Royal Society helped build momentum for public support of sanitary reform and was the clearest example of the Royal Society responding to a pressing community need. Despite complacency engendered by a salubrious climate, different views on the causes of disease, opposition to the pollution of waterways and reluctance by ratepayers and municipal councils to subsidise the cost of sanitary improvements, the sanitary reformers triumphed and municipal councils in Hobart and Launceston introduced a range of preventive health measures that contributed to the lowering of death rates by 1914 (Petrow 1995). Once sanitary improvements had been achieved and medical doctors formed their own association, papers on sanitary and medical subjects were rarely given but for nearly sixty years The Royal Society of Tasmania was the main forum for debate on public health reform.

\section{REFERENCES}

Batty Shaw, A. 1968: The oldest medical societies in Great Britain. Medical History 12 (3): 232-243.

Bedford, E.S.P. 1854: On the epidemics of 1852-3. Papers and Proceedings of the Royal Society of Van Diemen's Land 2(2): 460-477.

Bedford, E.S.P. 1863: On the origins of nervous force. Papers and Proceedings of the Royal Society of Tasmania: 1-6.

Bell, F. \& Millward, R. 1998: Public health expenditures and mortality in England and Wales, 1870-1914. Continuity and Change 13 (2): 221-249.

Berridge, V. 1990: Health and medicine. In Thompson, F.M.L. (ed.): The Cambridge Social History of Britain 1750-1950: Volume 3. Cambridge University Press, Cambridge: 171-242.

Biggs, A.B. 1884: Observations on Mr. R.M. Johnston's vital statistics. Papers and Proceedings of the Royal Society of Tasmania: 276-280.

Bromby, C.H. 1878: Water supply in relation to disease. Papers and Proceedings of the Royal Society of Tasmania: 56-62.
Campbell, N. \& Smellie, R.M.S. 1983: The Royal Society of Edinburgh (1783-1983): The first two hundred years. Royal Society of Edinburgh, Edinburgh: 186 pp.

Courier 1853: 12 November: 2.

Courier 1857a: 14 September: 2.

Courier 1857b: 21 October: 3.

Courier 1857c: 18 November: 3.

Craig, C. 1963: Launceston General Hospital: First hundred years. Launceston General Hospital, Launceston: 138 pp.

Cullen, M.J. 1975: The statistical movement in early Victorian Britain: The foundations of empirical social research. Harvester Press, Hassocks: 205 pp.

Curson, P. 1985: Edward Swarbreck Hall (1804-81). Pioneer Australian demographer: An assessment and selected bibliography. Journal of the Australian Population Association 2: 104-113.

Daunton, M. 2005: Introduction. In Daunton, M. (ed.): The Organisation of Knowledge in Victorian Britain. Oxford University Press, Oxford: 1-27.

Davidson, M. 1955: The Royal Society of Medicine: The realisation of an ideal (1805-1955). Royal Society of Medicine, London: $201 \mathrm{pp}$.

Davis, R. 1990: Open to talent: The centenary history of the University of Tasmania 1890-1990. University of Tasmania, Hobart: 256 pp.

Denison, W.T. 1854: On drainage and sewerage etc of towns, with special relation to the late epidemics in Hobart Town and Launceston. Papers and Proceedings of the Royal Society of Van Diemen's Land 2(2): 361-372.

Elkin, A.P. 1968: The challenge TO science, 1866: the challenge OF science, 1966. In Royal Society of New South Wales: A century of scientific progress: the centenary volume of the Royal Society of New South Wales: a history of several aspects of Australian scientific development, with particular reference to New South Wales, Society Science House, Sydney: 9-32.

Elkington, J.S.C. 1904: Insects and disease. Papers and Proceedings of the Royal Society of Tasmania: 1-11.

Examiner 1900a: 17 July: 7.

Examiner 1900b: 19 October: 7.

Finer, S.E. 1952: The life and times of Sir Edwin Chadwick. Methuen, London: $555 \mathrm{pp}$.

Goldman, L. 2002: Science, reform and politics in Victorian Britain: The Social Science Association 1857-1886. Cambridge University Press, Cambridge: 430 pp.

Hall, E.S. 1862: Climate and health in Tasmania. In Whiting, G.: The products and resources of Tasmania as illustrated in the International Exhibition, 1862. Hobart: Advertiser: 42-49.

Hall, E.S. 1863a: Hydraulics in reference to the sanitary requirements of the city of Hobarton, 12 May. Papers and Proceedings of the Royal Society of Tasmania: 1-12.

Hall, E.S. 1863b: Hydraulics in reference to the sanitary requirements of the city of Hobarton, 14 July. Papers and Proceedings of the Royal Society of Tasmania: 1-9.

Hall, E.S. 1865: Summary of weather and health in 1865. Papers and Proceedings of the Royal Society of Tasmania: 132-134.

Hall, E.S. 1872: Climate and vital statistics in Tasmania. In Hall, E.S. \& Abbott, F.: Results of five years meteorological observations for Hobart Town: ... and completing a period of thirty years. Government Printer, Hobart: 9-37.

Hall, M.B. 1984: All scientists now: The Royal Society in the nineteenth century. Cambridge University Press, Cambridge: 261 pp.

Harris, B. 2004: Public health, nutrition and the decline of mortality: the McKeown thesis revisited. Social History of Medicine 17(3): 379-407.

Haynes, E.F. 1978: Edward Swarbreck Hall: Medical scientist and social reformer in colonial Tasmania. Unpublished MA thesis, University of Tasmania.

Hoare, M.E. 1969: "All Things Queer and Opposite": Scientific societies in Tasmania in the 1840s. Isis: Journal of the History of Science in Society 60(2): 198-209. 
Hobart Town Daily Mercury 1858a: 5 January: 2.

Hobart Town Daily Mercury 1858b: 7 January: 2.

Hobart Town Daily Mercury 1858c: 11 January: 2.

Huch, R.K. 1985: The National Association for the Promotion of Social Science: Its contribution to Victorian health reform, 1857-1886. Albion 17(3): 279-300.

Hunting, P. 2002: The Royal Society of Medicine. Royal Society of Medicine, London: $505 \mathrm{pp}$

Inkster, I. \& Todd, J. 1988: Support for the scientific enterprise, 1850-1900. In Home, R.W. (ed.): Australian science in the making. Cambridge University Press, Cambridge: 102-132.

Ireland, E.W.J. 1910: Skin diseases treated by vaccine. Papers and Proceedings of the Royal Society of Tasmania: 370-375

Jamieson, J. 1902: Typhoid in Hobart and Melbourne, and the influence of drainage on its prevalence. Papers and Proceedings of the Royal Society of Tasmania: 95-99.

Jenkins, B.G. 1879: On a Probable Connection Between the Yearly Death-Rate and the Position of the Planet Jupiter in his Orbit. Journal of the Statistical Society of London 42 (1): 330-331.

Jenkins, C.F.H. 1965: A history of the Royal Society of Western Australia and its role in the community. Journal of the Royal Society of Western Australia 48(2): 33-44.

Johnson, T. \&Caygill, M. 1973: The British Medical Association and its overseas branches: A short history. Journal of Imperial and Commonwealth History 1: 303-329.

Johnston, R.M. 1884a: Remarks on the observed periodicity of the death-Rate, with suggestions as to its possible relation with the periodicity of solar and other super-terrestrial phenomena. Papers and Proceedings of the Royal Society of Tasmania: 236-239.

Johnston, R.M. 1884b: A rejoinder to Mr. A.B. Biggs's criticism on observations made in respect of "Observed periodicity of the death rate". Papers and Proceedings of the Royal Society of Tasmania: 280-282.

Johnston, R.M. 1887: How far can the general death-rate for all ages be relied upon as a comparative index of the health or sanitary condition of any community? Papers and Proceedings of the Royal Society of Tasmania: 13-35.

Johnston, R.M. 1896: The health of Hobart. Papers and Proceedings of the Royal Society of Tasmania: 1-21.

Kunitz, S.J. 1993: Diseases and the European mortality decline 1700-1900. In Kiple, K.F. (ed.): The Cambridge World History of Human Disease. Cambridge University Press, Cambridge: 287-293.

Launceston Examiner 1897: 3 September: 5.

Launceston Examiner 1898: 25 October: 5.

Lewis, M. 2003: The people's health: Public health in Australia, 1788-1950. Praeger, Westport: $311 \mathrm{pp}$.

Lilienfeld, D.E. 1978: "The greening of epidemiology": Sanitary physicians and the London Epidemiological Society 1830-70. Bulletin of the History of Medicine 52: 503-528.

Marks, E.N. 1959: A History of the Queensland Philosophical Society and the Royal Society of Queensland from 1859-1911. Proceedings of the Royal Society of Queensland 71: $17-42$.

Mault, A. 1886: The drainage of Hobart. Papers and Proceedings of the Royal Society of Tasmania: 24-33.

Mault, A. 1893 Remarks upon the disposal of the sewage of Hobart. Papers and Proceedings of the Royal Society of Tasmania: 188-193.

McWhirter, R. 2003: Doctoring status: The British Medical Association in Tasmania, 1911-1930. Unpublished BA Hons thesis, University of Tasmania.

The Mercury 1873: 7 October: supplement, 2.

The Mercury 1875: 20 October: 3.

The Mercury 1878a: 21 May: 3.

The Mercury 1878b: 23 May: 3.

The Mercury 1885: 16 July: 4.

The Mercury 1886a: 11 August: 3.

The Mercury 1886b: 28 September: 3.
The Mercury 1887: 12 May: supplement 1.

The Mercury 1896: 17 November: 3.

The Mercury 1897a: 7 April: 3.

The Mercury 1897b: 13 July: 3.

The Mercury 1898a: 26 April: 3.

The Mercury 1898b: 9 August: 4

The Mercury, 1898c: 28 October: 2.

The Mercury 1899: 28 March: 4.

The Mercury 1901: 29 October: 3.

The Mercury 1902a: 18 February: 3.

The Mercury 1902b: 21 June: 3.

The Mercury 1903: 4 December: 6.

The Mercury 1905a: 12 April: 6.

The Mercury, 1905b: 11 July: 7.

The Mercury 1905c: 8 August: 7.

The Mercury 1906a: 13 June: 6

The Mercury 1906b: 13 July: 6.

The Mercury 1908a: 10 April: 4.

The Mercury 1908b: 5 May: 7.

The Mercury 1909: 19 January: 2.

The Mercury 1923: 21 April: 13.

The Mercury 1931: 16 July: 6.

Morton, A. 1900-01: Some account of the work and workers of the Tasmanian Society and the Royal Society of Tasmania, from the year 1840 to the close of 1890. Papers and Proceedings of the Royal Society of Tasmania: 109-126.

Nowell, E.C. 1875: On the vital statistics of Tasmania, with especial reference to the mortality of children. Papers and Proceedings of the Royal Society of Tasmania: 108-126.

NS168/1/1: Minutes of the Tasmanian branch and branch council of the British Medical Association 1911-1916. Tasmanian Archive and Heritage Office.

Paull, J.D. 2011: William Russ Pugh's remarkable life: Natural scientist, innovative anaesthetist and founding member of the Royal Society of Tasmania. Anaesthesia and Intensive Care 39, supp. 1: 18-26.

Pearson, J. 1943: Centenary of the Royal Society of Tasmania. Papers and Proceedings of the Royal Society of Tasmania: 223-231.

Pescott, R.T.M. 1961: The Royal Society of Victoria from then, 1854, to now, 1959. Proceedings of the Royal Society of Victoria 73 n.s.: $1-40$.

Petrow, S. 2003a: The antiquarian mind: Tasmanian history and the Royal Society of Tasmania 1899-1927. Papers and Proceedings of the Royal Society of Tasmania: 137: 67-74.

Petrow, S. 2003b: A municipal heaven: Launceston 1870 to 1914. Launceston Historical Society Papers and Proceedings: $16-25$.

Petrow, S. 1995: Sanatorium of the south? Public health and politics in Hobart and Launceston 1875-1914. Tasmanian Historical Research Association, Hobart: 218 pp.

PPRST 1911: Annual general meeting 1911. Papers and Proceedings of the Royal Society of Tasmania: 401-405.

PPRST 1872: Minutes of meeting of March 1872. Papers and Proceedings of the Royal Society of Tasmania: 1-4.

PPRST 1907: Report of the Royal Society of Tasmania for the Year 1907. Papers and Proceedings of the Royal Society of Tasmania: 1-li.

Richardson, Benjamin Ward 1877: The Glandular Origin of Contagious Diseases. Nature 16(414): 480-486.

Rimmer, W.G. 1981: Portrait of a hospital: the Royal Hobart. Royal Hobart Hospital, Hobart: 328 pp.

Roberts, E.J. 1906-7: The germ as a friend in therapeutics: Notes on the opsonic index. Papers and Proceedings of the Royal Society of Tasmania: xli-xlii.

Roe, M. 1999: Life over death: Tasmanians and tuberculosis. Tasmanian Historical Research Association, Hobart: 234 pp.

Roe, M. 1984: Nine Australian progressives: vitalism in bourgeois social thought, 1890-1960. University of Queensland Press, St. Lucia: 328 pp. 
Rogers, R.S. 1922: A history of the Society, partly in its relation to other institutions in the State. Transactions and Proceedings of the Royal Society of South Australia 46: 615-649.

RSA/H/5: Minute book of the Royal Society of Tasmania Council 1879-1902, Royal Society of Tasmania papers, University of Tasmania Archives.

Somerville, J. 1943: The Royal Society of Tasmania 1843-1943. Papers and Proceedings of the Royal Society of Tasmania: 199-221.

Sprott. G. 1896: Tuberculosis. Papers and Proceedings of the Royal Society of Tasmania: 45-68.

Sprott, G. 1897: The disposal of our dead by cremation. Papers and Proceedings of the Royal Society of Tasmania: 13-24.

Szreter, S. and Hardy, A. 2000: Urban fertility and mortality patterns. In Daunton, M. (ed.), The Cambridge urban history of Britain, Volume 3: 1840-1950. Cambridge University Press, Cambridge: 629-672.
Ward, W.F. 1885: The impurities of water in relation to typhoid fever. Papers and Proceedings of the Royal Society of Tasmania: $116-128$.

Wilkinson, E.H. 1902: Sewage purification and disposal. Papers and Proceedings of the Royal Society of Tasmania: 100-105.

Winter, G. 1972: "For ... the Advancement of Science": The Royal Society of Tasmania, 1843-1885. Unpublished BA Hons thesis, University of Tasmania.

Worboys, M., 2000: Spreading Germs: Disease Theories and Medical Practice in Britain, 1865-1900. Cambridge University Press, Cambridge.

(accepted 6 August 2013) 